\title{
Translators' Prefaces to Literary Works a Means to Visibility or Invisibility?: A CDA Approach to Analyze Translators' Prefaces as Part of the Paratext
}

\author{
Sarah Fayed*
}

\section{Introduction}

The importance of the preface as a tool that could give access to all kinds of insights that pertains to the socio-cultural setting surrounding the process of forming a book cannot be stressed enough. Through Gérard Genette and Marie Maclean's (1991) analysis, the preface is seen as part of the paratext, (specifically peritexts) which is the means through which a text forms itself into a book and presents itself to readers and the public in general. According to Kathryn Batchelor (2018), translation studies as a discipline was established through the efforts of anthologies covering reflection on translation, particularly using translators' prefaces. She also asserts that paratext (including the preface) is a chance for translators to intervene or adapt a text into its new context. Moreover, Genette (2001) mentioned how author Jorge Luis Borges used the term "vestibule" to describe how the preface can give the reader the option of either proceeding or retreating. It was also described as an "undecided zone" between the inside and the outside. It has no defining limits, either towards the text or towards the "discourse of the world on the text" (p.28). Through these assertions about the importance of the preface as a link between the text and the reader and also as a form of mediation that can help the reader access the text in a certain context, it becomes abundantly clear that this importance increases significantly in the context of a preface written by a translator for a translated literary work.

Very little research has been done in the area of exploring translators' prefaces, specifically as pertains to the different features and their functions within a socio-cultural context and the mediating role of the translator. Therefore, it is important to first clarify the concept of using translators' prefaces as research tools and a means to a more comprehensive analysis in translation

\footnotetext{
${ }^{*}$ Assistant Lecturer in the English Unit, Faculty of Engineering, British Univerity of Egypt (BUE).

Cairo Studies in English 2020(1): https://cse.journals.ekb.eg/
} 
studies. Tahir Gürçağlar (2011) discussed the idea of a translator's preface and how that independently they can have a major role in how the reader engages with the translated text. He went on to state that paratexts can indicate the level of visibility or invisibility of a translator; moreover, it can reveal important information about the target culture, readership and how they align with the text itself. Additionally, Rodica Dimitriu (2009) cemented this assertion by stating that the field of translation studies owes prefaces to canonical literary works written by translators for the important research that aided in the creation of traditional translation theory.

Through using Norman Fairclough's three-dimensional framework and through employing Venuti's theory on invisibility with reference to a translator's situation in relation to his/her target culture, this paper attempts to analyze three sets of prefaces covering three Source Texts. The source texts (STs) include novels written in Spanish, Japanese, and Russian: Love in the Time of Cholera by the Colombian author Gabriel García Márquez (1985), Kokoro by the Japanese author Natsume Sōseki (1914), and A.S. Pushkin. Collected Works in Ten Volumes. Volume 5. Novels. Tales by the Russian author Alexander Pushkin (1975). Tihe translated Target Texts (TTs) include Arabic and English translations of the above three STs. Moreover, excerpts from interviews with the translators (both translators who translated into Arabic and those who translated into English) are included to further clarify the connection between the discourse and social practices. The source texts translated into Arabic (which will be referred to as TT1) include hikēyāt Pushkin: majmū'a qașașiya (2018) by Tawfik Ali Mansour (a translation of A.S. Pushkin. Collected Works in Ten Volumes. Volume 5. Novels. Tales by Alexander Pushkin 1975), Kokoro (1988) by Abdelwahed Mohamed (a translation of Kokoro by Natsume Sōseki 1914), and al-hub fí zaman al-kolira (2013) by Saleh Almani (a translation of Love in the Time of Cholera by Gabriel García Márquez 1985). Furthermore, a parallel translation of the above source texts into English (which will be referred to as TT2) included: Alexander Pushkin Novels, Tales, Journeys The Complete Prose (2016) by Richard Pevear and Larissa Volokhonsky, Kokoro (2010) by Meredith Mckinney and Love in the Time of Cholera (2014) by Edith Grossman.

The paper aims to explore how the paratext (preface of translated literary books in specific) production and interpretation, translator's profile, and social practice impact translators' construction of their identities as translators/authors within their target culture. The research question is: how does the relationship between invisibility, social practice, and the translator's identity/role combined impact translators' choices in writing prefaces for translated literary works? 


\section{Theoretical Underpinnings}

\section{Critical Discourse Analysis}

Fairclough (2010) stated that CDA is not an analysis of discourse but rather an "analysis of dialectical relations between discourse and other objects, elements or moments, as well as analysis of the "internal relations "of discourse" (p.4). In that sense it is important to perceive all combined elements surrounding a text to reach sound judgments about why such text is presented in such a way and what meaning and interpretation about the text are being constructed.

In his book Critical Discourse Analysis: the Critical Study of Language, Fairclough also stated that "Language is a material form of ideology, and language is invested by ideology" (1995, p. 73). The intricate connection between language and ideology once established was found to be ever-evolving and manifesting itself in the considerable number of layers of analysis being discovered and created on regular basis. Fairclough (1995) also highlighted the significance of how ideology through discourse can create and recreate relations, subjects, and objects in the social world. When considering how very much deeply imbedded in language the translation process is, it would come as no surprise of how well in renders itself as a rich subject matter for critical discourse analysis approaches and models. Furthermore, the idea of how the process of interpretation in case of analysis of the text is doubled, once by the translator for the Source Text (ST) and then the reader through the Target Text (TT) and how the translator provides commentary in the preface about that process, automatically produces a loaded and charged text with a lot of areas for analysis. Multiple ideologies can resurface since there are already two ideologies at play (that of the ST and that of the TT). Van Dijk (2016) stated that Critical Discourse Study (CDS) would typically address a text through relating it to the social structures. Aspects such as the identity of the author, the affiliation, and the publishing houses will always be considered. Consequently, this is the method that would best explain why a text is presented as it is.

\section{Prefaces as Part of the Paratext}

Genette (2001) described the paratext as a zone between text and off-text. "A privileged place of pragmatics and a strategy, of an influence on the public, an influence that - whether well or poorly understood and achieved - is at the service of a better reception for the text and a more pertinent reading of it". One good example to show the importance of paratext is the idea of how we would read Ulysses by James Joyce if not for the title of the book? (p.28). Kathyrn Batchelor (2018) stated that any attempts at outlining a consistent and systematic view for describing translations required the use of paratextual material rather than the 
translation itself. There are questions about how the translation is identified "(as a "translation", or as an "adaptation" or "imitation")?, Is the translator's name mentioned anywhere?, and Does the translator or the editor provide any metatextual comment (preface, footnotes)?" All these concerns about what the translated text is and how could it be described properly can only be addressed through the existence of paratextual material (p.25). According to Flynn (2013), although paratexts might be representative in nature in terms of their purposes and functions, they are still written by translators who could be creative, and they can introduce a new author to new readers. The notion of them selecting this specific work with all the types of discourse that it entails can even serve as an area for further research. Genette (1997) has multiple classifications for different aspects of the paratext to name a few: title, subtitles, preface, foreword, introduction, and notes. The main focus of this paper is the preface.

\section{Translator's Role}

Lawrence Venuti (2008) mentions in his book The Translator's Invisibility that "the point is rather that the precise nature of the translator's authorship remains unformulated, and so the notion of authorial originality continues to stigmatize the translator's work" (p.6). One of the interpretations of this statement is the concept of how the translator is the author of the preface and since there is already the sense that his authorship is in question when it comes to the translated text, then through the absence of a preface, translators will automatically become even more invisible. According to Isabelle Bilodeau (2012), bearing in mind how little power a translator has by virtue of his/her role and because of how marginalized he/she is, it would seem appropriate to allow for this marginal mark of "agency" to the translator. In that sense, translators' prefaces should be allowed to reflect more of who they are and their role in translating the texts. Venuti's (2008) concept of invisibility and domestication indicate, in a simplistic sense, how a translator would successfully render a text in the target language with such fluency (and with ample disregard of the many intricacies and specific and unique features of the source language itself) as to bestow a sense of originality to the translated text that it becomes a "source text" in the target language which would somehow cause the translator's invisibility.

Through looking at translators who, to a great extent, adopted domestication methods while translating the same source texts but in two different target cultures, one can discover the labels of visibility versus invisibility for translators and the extent of how without a purely Anglo-American cultural approach, a varying level of visibility and invisibility might emerge. In this paper, a preface is defined as any information stated by the translator as a 
forward/introduction/translator's note and might also include the translation of the original source's (OS) author's preface by the translator (in case of indirect translation ITr).

\section{Methodology}

The nature of the data being analyzed in this paper requires a specific type of analysis; thus, the three-dimensional framework designed by Fairclough (1992) is employed (Figure 1). The model includes three main dimensions "social practice", "discourse practice", and "text". The paper mainly utilizes the dimension of social and discourse practices. In analyzing the social practice dimension, Fairclough stated that there is a need for exploring the relation of power and domination (2010). While the discourse practice dimension is concerned with the different processes involved in how the text is produced and interpreted, this carries even more significance when it comes to translated texts.

Fairclough (2001) mentions that social actors within any practice would likely produce different representations including reflexive ones in the course of their activity within said practice. They are also likely to recontextualize other practices within their own, by applying this to the process of how translators construct and reconstruct identities and realities. This happens through the complicated process of translating and rendering an already quite challenging literary text into a reconstructed new text with the assumed intention of preserving the integrity as much as possible. It would make sense to have such different features and functions resurfacing in the only outlet for translators to express their visibility and identity.

When looking at the translator's preface several

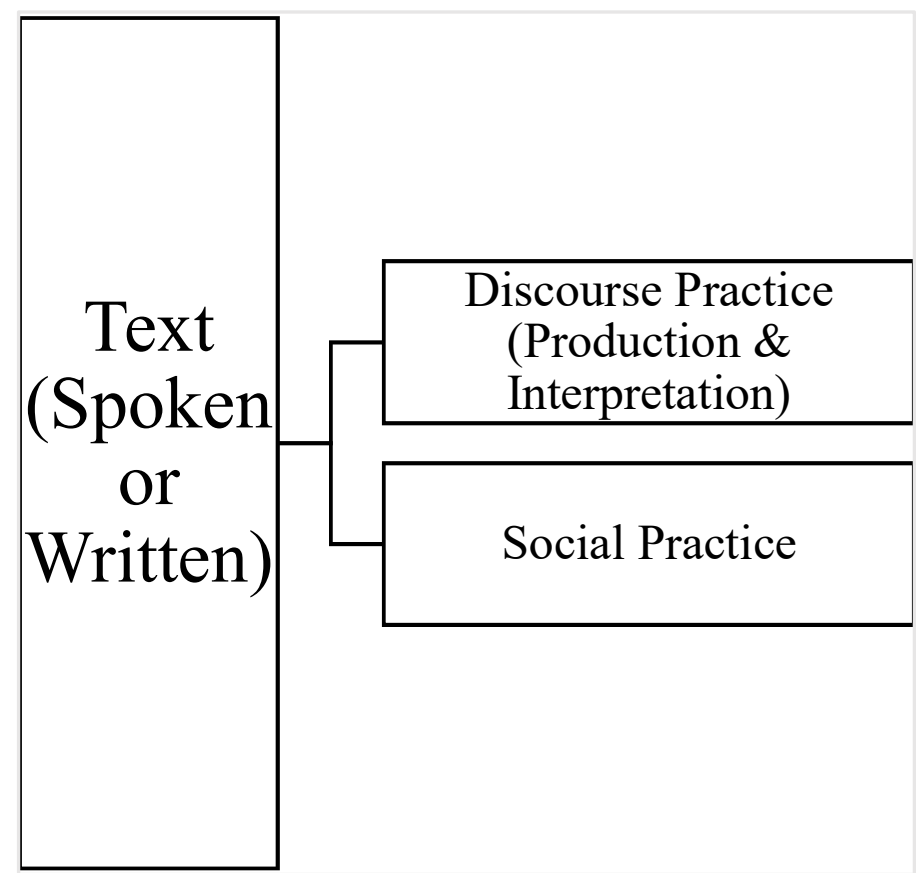

Figure 1. Fairclough's (1992) Three-Dimensional Framework for Analyzing Discourses features come to mind; for instance, there might be some that are for specific functions such as informing readers about the translated text, providing 
background about the author, mentioning other works by the author, and maybe recontextualizing the text so that it better fits with the target audience sensibility. All these functions can be served through the generally accepted format of a preface; however, the translators who wrote the prefaces seem to use different structures that better serve the prevailing discourse practice in their culture or in instances where power and domination and invisibility interfere. These features are added to the preface to serve self-promotion or other ideologically related objectives.

\section{Sample Description}

In this paper, three distinctly different texts with three different languages were used. The source texts (STs) include novels written in Spanish, Japanese, and Russian: Love in the Time of Cholera by Colombian author Gabriel García Márquez (1985), Kokoro by the Japanese author Natsume Sōseki (1914), and A.S. Pushkin. Collected works in ten volumes. Volume 5. Novels. Tales by Russian author Alexander Pushkin (1975). The historical timeline ranges from as early as 1830's for the Russian collection of prose by Alexander Pushkin, then 1914 for the Japanese novel Kokoro by Natsume Soseki, and finally, the most recent is 1985 for the Spanish Love in the Time of Cholera by Gabriel García Márquez.

The paper focuses on comparing the differences between the prefaces written to the above works in first Arabic translations then English translations. Below are a list of the translations of the three STs in Arabic first and then a list of the works translated in English.

\section{Works translated into Arabic (TT1):}

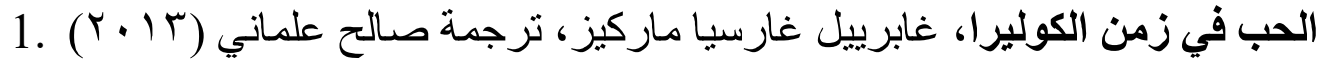

Love in the Time of Cholera, Gabriel García Márquez (1985), translated into Arabic by Saleh Almani (2013)

G.G. Marquez (2013), Al-hub fi zaman al-kolera [Love in the Time of Cholera], transalted by Saleh Almani, Beirut: Al-Mada.

2. كوكورو، ناتسومس سوسيكي، ترجمة عبد الواحد محمد (911) (191) )

Kokoro, Natsume Sōseki (1914), translated by Abdel-Wahed Mohamed (1988).

Natsume, S., \& Mohamed, A. (1988). Kokoro, Baghdad: Dar Al-Maamoun.

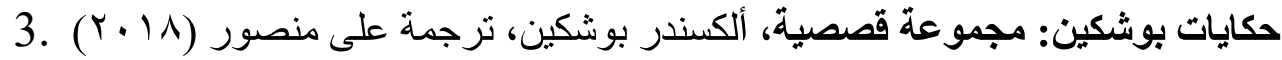

Pushkin's Tales: a Collection of Stories, Alexander Pushkin, translated by

Tawfik Ali Mansour (2018).

Pushkin, A. S., \& Mansour, T. A. (2018). hikāyāt Pushkin: majmū'a qașașiya [Pushkin's tales a collection of stories].Cairo: Al-Maktab al-Arabi lel-Maaref. 
The historical timeline for the Arabic translations includes one translation in 1988 by Abdel-Wahed Mohamed and two fairly recent ones one 2013 by Salah Almani and one as recent as 2018 by Tawfik Ali Mansour.

\section{Works translated into English (TT2):}

1. Love in the Time of Cholera (2016) translated by Edith Grossman.

Marquez, G. G., \& Grossman, E. (2016). Love in the Time of Cholera. New York: Penguin Publishing Group.

2. Kokoro (2010) translated by Meredith Mckinney.

Natsume, S., McKinney, M. and Natsume, S. (2010). Kokoro. New York: Penguin Publishing Group.

3. Alexander Pushkin Novels, Tales, Journeys The Complete Prose (2016) translated by Richard Pevear and Larissa Volokhonsky.

Pushkin, A. S., Pevear, R., \& Volokhonsky, L. (2016). Novels, Tales, Journeys: The Complete Prose of Alexander Pushkin.

The English counterparts would seem to be all fairly recent, with one translation in 2010 by Meredith McKinney and two translations in 2016 by Edith Grossman, and Richard Pevear and Larissa Volokhonsky.

An important fact to mention about the sample is that two of the TT1s (Arabic translations) used indirect translation which entailed using a mediating text in English to help render the texts into Arabic. The figure below (Figure 2) clarifies
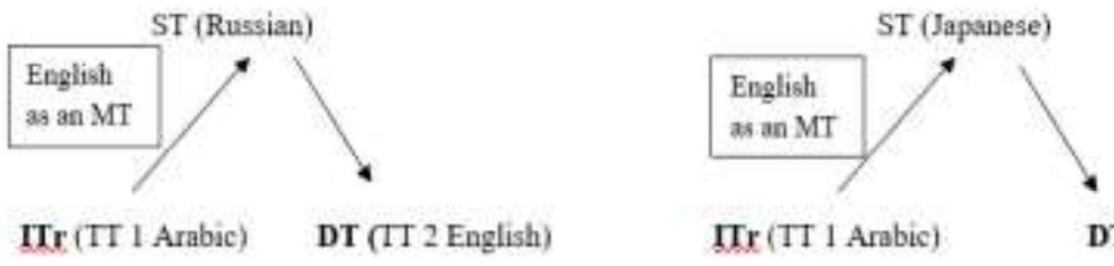

$\operatorname{Tr}$ (TI Arabic)

DT (T2 English)

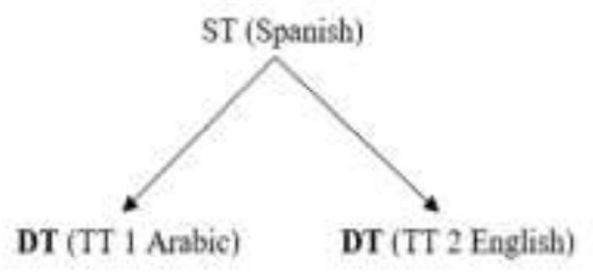

Figure 2. STs and TTS with indirect translation ITSS indicate 
the Direct Translation (DT) and the Indirect Translation (ITr) and the Mediating Text (MT) language used.

\section{Analysis of Prefaces}

Comparative analysis of parallel features in the three sets of prefaces:

The common features expected in this discourse set would be information provided to serve some of the following functions:

a. About the author

b. Other works by the author

c. Introducing the book

d. Notable discoveries or context concerning the original text

A. Russian ST A.S. Pushkin. Collected works in ten volumes. Volume 5. Novels. Tales (1975) by Alexander Pushkin.

It was fairly easy to detect the differences between the translators of the Arabic TT in comparison to the English TT; there was certain information about the author that was stated in different styles. Ironically, it seemed in both parts as an attempt at domestication; the Arabic translator tried very hard to Arabize the author to the extent of claiming his ancestry can be traced to the Arabian Peninsula.

$$
\text { وقد أثيع أن أصوله تمتد بجذورها إلى الجزيرة العربية، الأمر الذي يحتاج إلى الدراسة }
$$

"There are claims that his ancestry traces back to the Arabian Peninsula, which is a claim in need of more research". 1

It was also obvious that the Arabic translator's ideology was quite evident, particularly when the concept of atheism was introduced in the preface:

$$
\text { و رقيدة أخرى ليس بالإلحاد، نلمس في كتاباته الإيمان بالله، فمن كفر بإحدى العقائد و آمن }
$$

"And although he was accused of atheism, there are still glimpses

of faith in his writings. It would not be right to confuse not

believing in a certain faith with not believing at all."

${ }^{1}$ All translations in this article are italicized and are the author's own. 
One idea that could be concluded about the Arabic preface is that it is a strong attempt at constructing a rich and full ideological presence that establishes a greatly domesticated version of the book to the readers in the target culture.

Looking at the choices of Quranic verses (above) and their placement and the dedication to the fellow translator (below), one can notice how the translator heavily self-promoted himself within features that also served his attempts at domesticating the content to a more middle-eastern/Arab socio-cultural context.

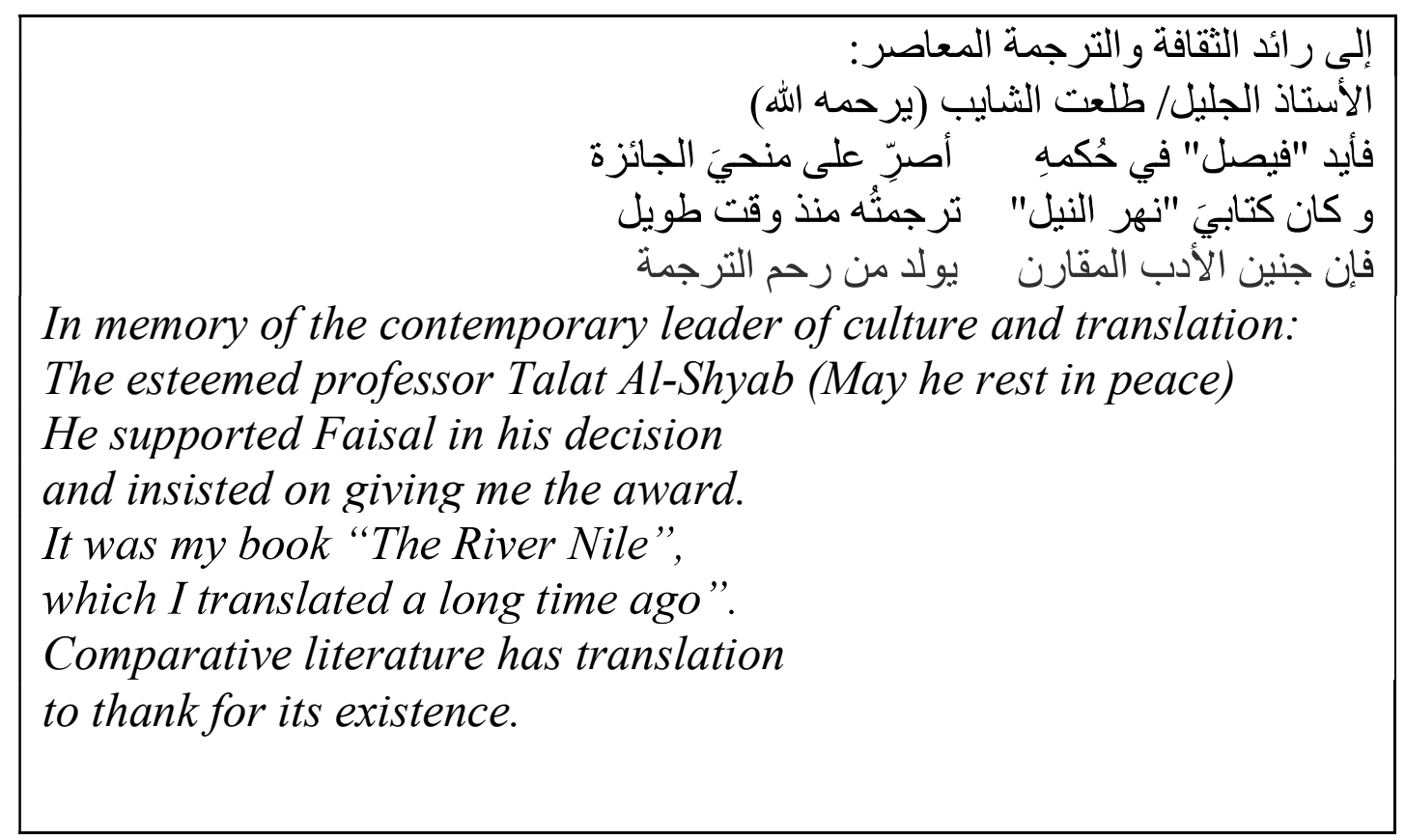

$\mathrm{Li}$ (2017) stated that there is a need to consider the power relations between cultures/languages since it is assumed that the indirect translation takes place when both the source language and the target language are not dominant while the mediating language is dominant. This adds weight to the argument of how indirect translation might place the translator in a position where he would make different decisions about his/her translation choices. It can be argued that it adds to the already heavily charged relations within the text which causes many instances of self-promotion in the order of discourse of the translator's paratext material and ultimately leads to attempts at reconstructing the translator's identity (Fairclough, 2010).

B. Japanese ST Kokoro (1914) by Natsume Sōseki

The extracts from both prefaces show many features in common in terms of the function of the preface and the selection of information to be included. 
Arabic Preface (TT1)

$$
\begin{aligned}
& \text { و وموماً، إن معظم أعماله رصينة وذات هدف أخلاقي واجتماعي عال أسبغ عليها، ولا }
\end{aligned}
$$

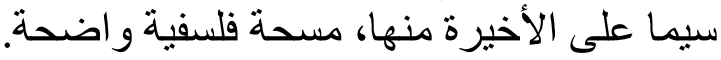

His works are for the most part solemn and imbued with moral and social values, which rendered his final work in particular with a very evident philosophical inclination."

\section{English Preface (TT2)}

It is the human condition itself that is Soseki's primary interest, here and elsewhere in his work. In Kokoro he achieved his finest expression of this great theme.

Arabic Preface (TT1)

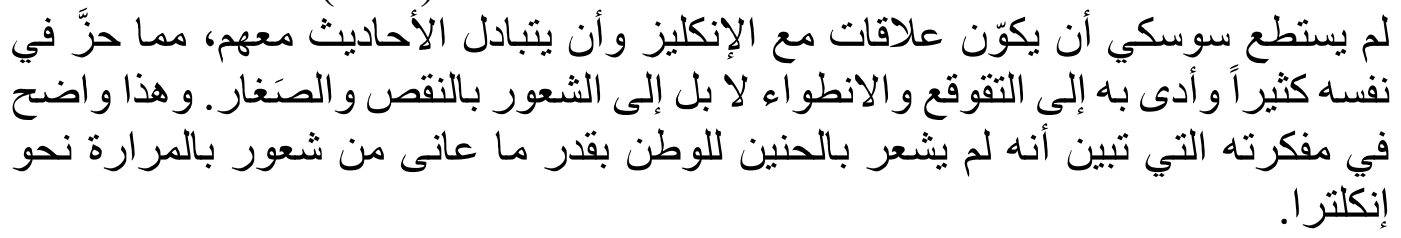

Soseki was not able to build relationships or converse with the British, which haunted him and caused his withdrawal and isolation and it even went further to cause a serious case of insecurity and self-doubt. Looking at what he wrote in his diary, one can see the extent of that misery in that he actually did not feel home sick as much as he felt animosity towards England.

English Preface (TT2)

In 1900 the Japanese government selected him to spend two years studying in London; the intention was that he would increase the nation's cultural capital by bringing back a deeper understanding of the West. But Soseski was miserable in England, isolated and alienated from everything around him, which seems to have brought him close to nervous collapse.

It is possible to capture key points that were found still relevant and important in the English counterpart more than twenty years later.

Interestingly enough, multiple terms that are used to describe the painful experience Soseski faced in England are quite similar in both texts. This is maybe another argument for the idea of how stigmatizing indirect translation could lead to a significant gap in translated world literature. A translator from 
Iraq, a country that chances of its people reading Japanese Literature is limited to say the least, would definitely benefit from a translation of Japanese literature albeit it being an indirect one using an English mediating text. Li (2017) discussed elaborated on this idea in a study titled The Complexity of Indirect Translation: "Nonetheless, despite its reputation as a reluctant choice and inferior because of its second-hand nature, it has been crucial to the dissemination of literature of non-major cultures or in less spoken languages. World literature would have lost much but for the diverse literary genres and forms that have gained currency through translation" (p. 182).

\section{Spanish ST Love in the Time of Cholera (1985) by Gabriel García Márquez}

This pair of preface versus no preface is quite interesting; having read a number of books translated by the Arabic translator, it can be safely said that he rarely provides prefaces. This added to the fact that the translator who translated into English also did not provide a preface was quite interesting. Some arguments could be that the Arabic translator has enough recognition in the source language community itself and that he does direct translations which might have led to lesser overt attempts at self-promotion. Furthermore, choosing to provide minimal information about the author only, and given the choice of information mentioned in the preface, it can in fact be a small window into the translator's view of the political happenings in Latin America.

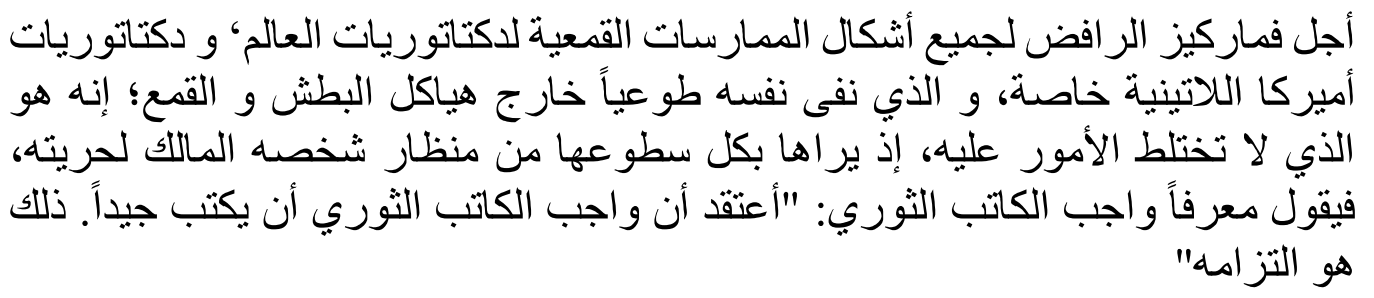

Indeed, because the ever-revolutionary Marquez, who rejects all forms of oppression exercised by all dictatorships and specifically Latin American dictatorship is one who does not get confused, for he sees everything through his own free vision. He defines role of a revolutionary writer as someone who is committed to the concept of writing well.

The English missing preface case is explained easily by widening the scope of information to include more about the translators; when putting these two dimensions together, the context allows for a better understanding. The no preface is simply a declaration of how, if given enough validation from the ST 
author, that the mere name of the translator on (not the cover, or the first page) the second page in a fairly small font is enough.

\section{Analysis of the Translators' profiles}

There is a need to explore the context through which the translators' prefaces emerged, hence an understanding of who they are and through analyzing some excerpts of interviews, some insight into the meaning-making process and social practice may be gained. According to Venuti (2008), a translator's authorship does not ever receive full legal recognition, since the process of controlling the translation is by default the author's responsibility, to the extent where the translator's rights are compromised. Athough Venuti was discussing American and British translators, when looking at the below excerpt from an interview with Saleh Almani (who translated Love in the Time of Cholera), it is clear that the same problem is present in Arab/Middle East contexts.

Profile 1. "Saleh Almani (Palestine) born in Homs, Syria, in 1949. Since the late 1970s, he has completed translations of over 100 works of Latin American literature into Arabic, including dozens of books by the most prominent names in Latin American writing. His translations have been published across the Arab world and he has participated in numerous Arab and international conferences, seminars, and research groups working on translation as well as overseeing literary translation workshops at the Cervantes Institute, Damascus. He has received numerous awards and honors for his work (IPAF, 2017)."

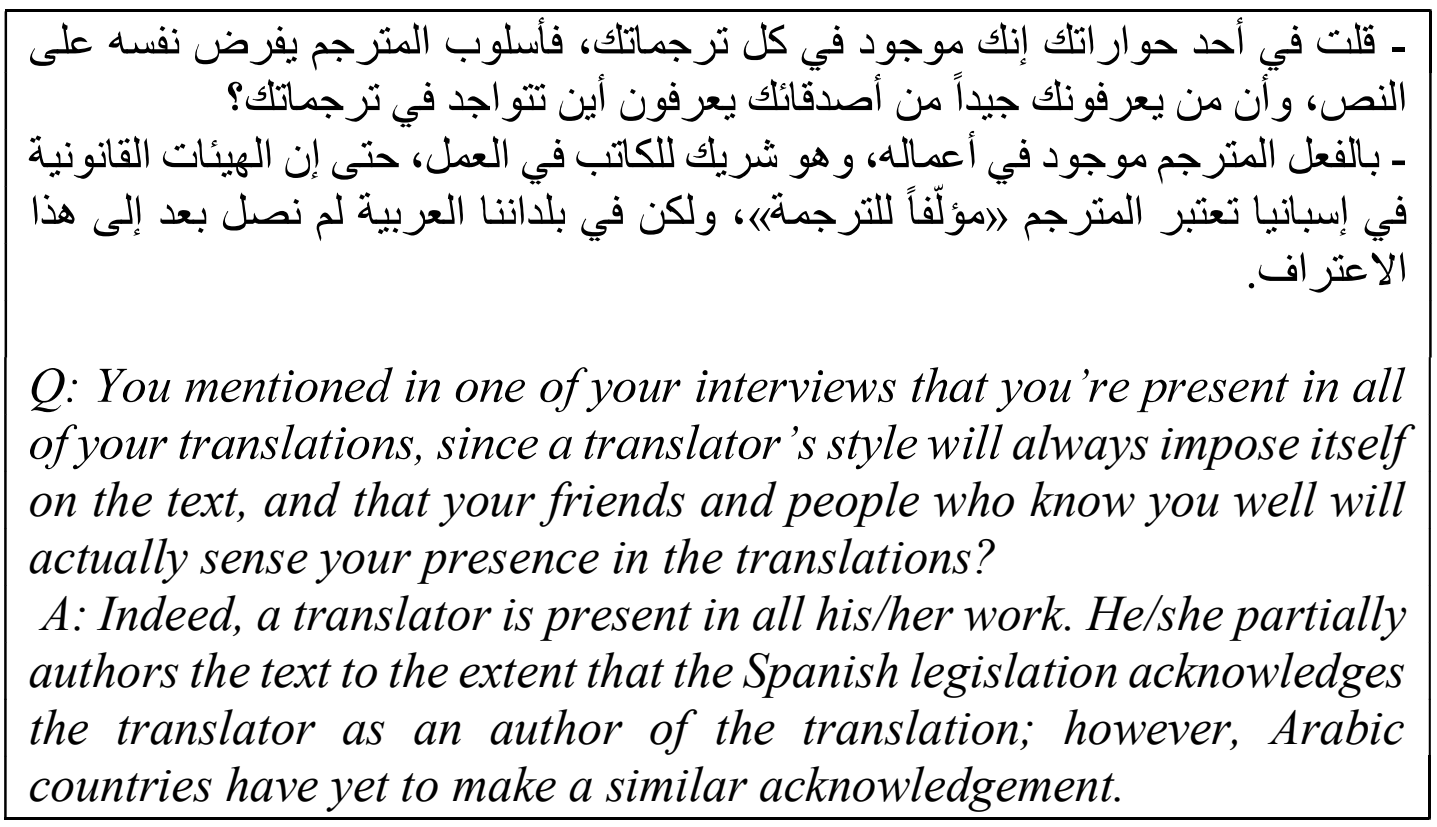


Profile 1 shows the background retrieved from a website through searching for the translator's name in English. One ironic observation is that the translator's background is more accurately discovered through using English rather than Arabic, the author's actual target language. It would seem that a translator translating into a less powerful or dominant target language would strive to domesticate all works he/she translates, and that the real presence or visibility to be obtained is through how many books from all over the world are provided in a completely Arabized format.

Profile 2. The only results found online about Tawfik Ali Mansour are related to his award, and there is only one personal blog that describes his life and upbringing. This time, the information is in Arabic the target language. The choice of words in these excerpts is quite interesting; on the one hand, there is the "written and translated more than sixty books" which sadly could not be verified. Moreover, the stress on his military career and providing the timeline is a very good example of how the notion of creating or reconstructing an identity that is more aligned with dominant social and political discourse practices.

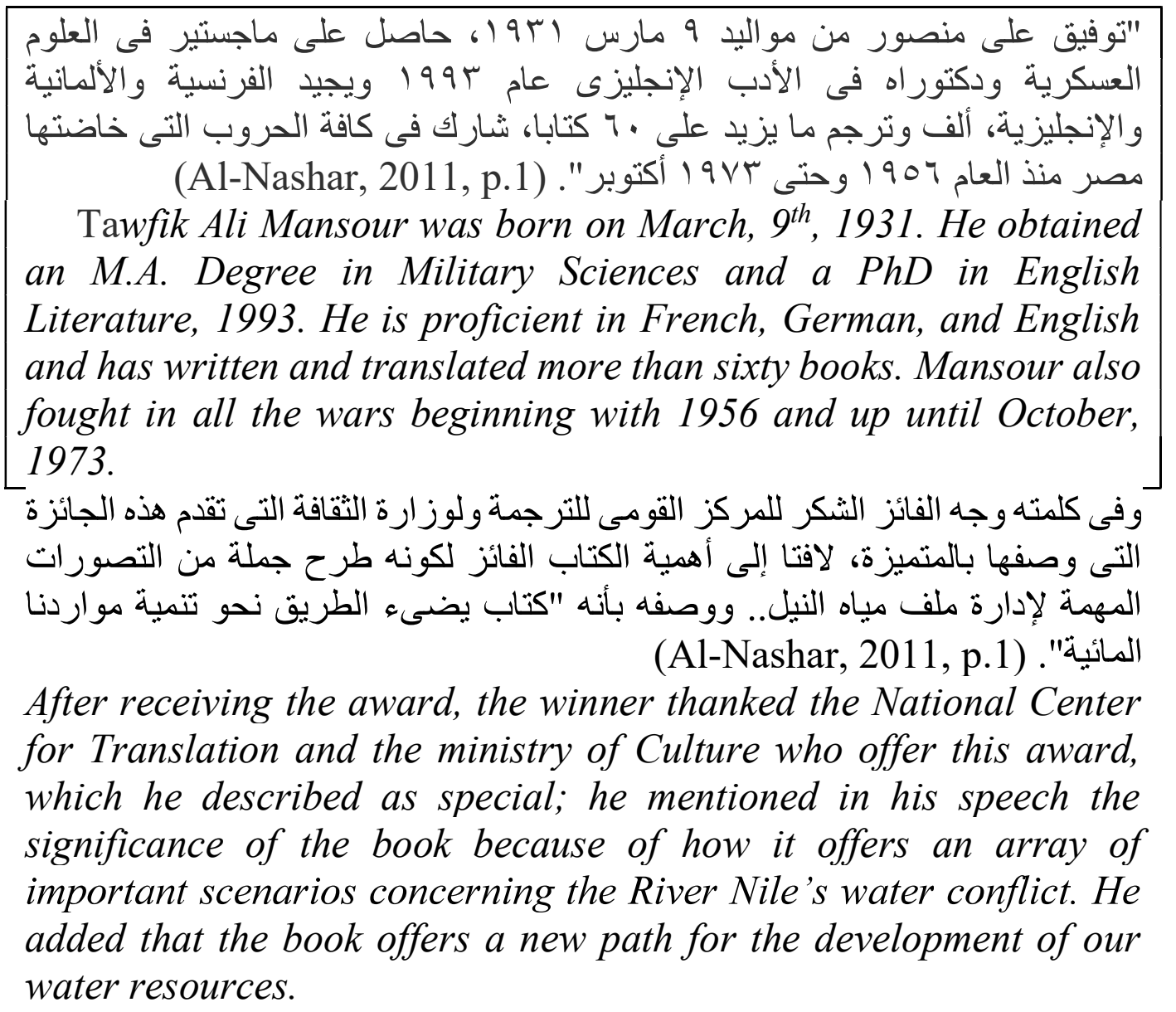


Profile 3. "Abdelwahed Mohamed was born in Maysan, Iraq; he is a professor and works in the English Department in an Iraqi university. He was the dean of the faculty of languages and he has been in academia for almost forty years (Youssef, 2012)." The information available online was quite scarce. It would be safe to assume that the translators using English as the target language are aligned with concepts of domestication as proposed by Venuti (2008).

The below excerpt is from Abdelwahed Mohamed's interview, who translated Koroko; and by placing him in comparison with the translator who translated Koroko into English, some word choices would be interesting to look at. Both translators showed genuine interest in Japanese literature in a random approach; however, comparing words such as "hmm, that's actually quite nice" and "and the first publisher I tried accepted it" versus "I eagerly held as if it was a much sought-after treasure" and "I happily snatched.." reinforces the idea of the difference in power and ideologies as pertains to the target culture and language. With a dominating target language like English, not only is English translation of Kokoro much sought-after for English (as a target language) readers, but also her marginalized target languages (i.e. Arabic) will use English as a mediating text to translate Kokoro into Arabic.

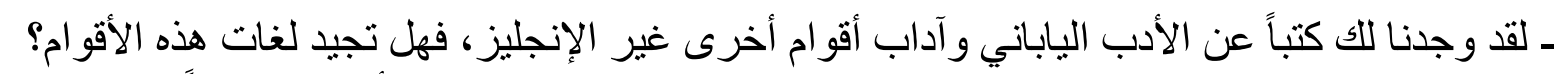

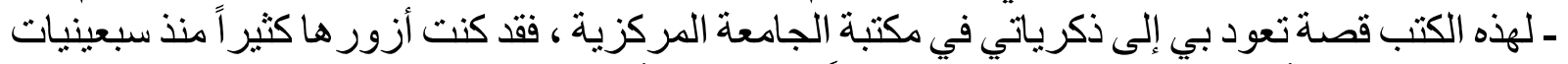

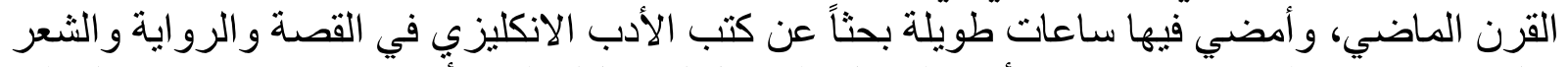

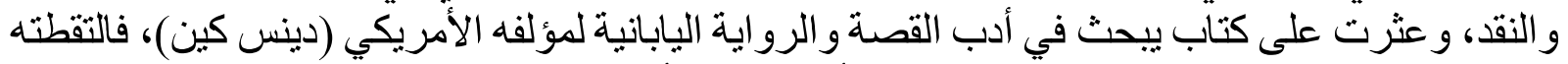

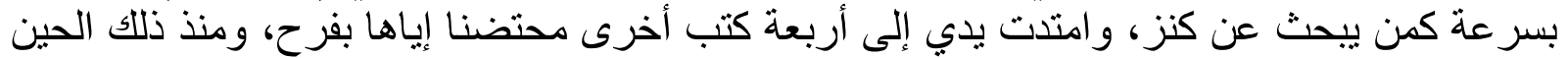

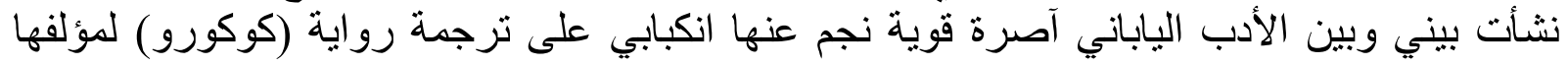

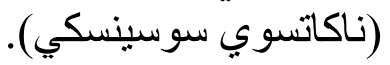

Q: There are some Japanese literature and other non-English literature books translated by you, so do you know how to speak these languages?

A: This takes me back to the days I spent in the Cairo University Central Library; I used to visit there a lot back in the seventies and I spent a lot of time searching for English books that covered poetry, novel, short story and criticism. I did find a book by Donald Keene discussing modern Japanese literature, that I eagerly held as if it was a much sought after treasure and I happily snatched four more books. I developed a strong bond with Japanese literature since then, and what followed was my diligent efforts of translating Kokoro by Natsume Sōseki. 
Profile 4. "Meredith McKinney studied modern and classical Japanese Literature at the Australian National University, where she is now a Visiting Fellow. She lived for many years in Kyoto, where she taught and translated. Her main publications include re-translations of The Pillow Book, as well as of Soseki Natsume's Kusamakura and Kokoro, all in Penguin Classics. She has translated Yoshikichi Furui's White-Haired Melody for JLPP. In 2000 she won the Japan-U.S. Friendship Commission Translation Award, for Yoshikichi Furui 's Ravine and Other Stories. She has also translated A Thousand Strands of Black Hair, by Seiko Tanabe, and Masahiko Shimada's Death by Choice for JLPP. (JLPP, 2010)." An interesting observation about this particular translator (Mc Kinney) is that all the lengthy details to be found about her were provided by Japanese sources. Meredith McKinney who translated Kokoro wrote: "One day I came across a writer who fascinated me-Furui Yoshikichi. He was so weird and compelling that I needed to really grasp what he wrote, not just read it superficially, and I decided that the best way to do that was to try translating it into English" (McKinney \& TranNet, 2018, p. 2).

The words used in the below quote are an indicating example of how a target language dominates in the process of translation only because the translator's English is reader-friendly rather than any other specific criteria. Consequently, with languages and cultures that are marginalized, the notion of having their seminal works read by others is too tempting to allow for much consideration.

One day I found a little book called Saigyo Monogatari (The Tale of Saigyo). The Language was fairly simple the poems were lovely, and when I finished translating it I thought, " $\mathrm{hmm}$, that's actually quite nice, why don't I try to publish it?" Luck was with me again, and the first publisher I tried accepted it.

Profile 5. Another clear example of adopting a domesticating approach is the excerpt below; a speech delivered by Edith Grossman (translated Love in the Time of Cholera) at the 2003 PEN Tribute to Gabriel García Márquez, held in New York City on November 5, 2003, where she explains her method:

Fidelity is surely our highest aim, but a translation is not made with tracing paper. It is an act of critical interpretation. Let me insist on the obvious: Languages trail immense, individual histories behind them, and no two languages, with all their accretions of tradition and culture, ever dovetail perfectly. They can be linked by translation, as a photograph can link movement and stasis, but it is disingenuous to 
assume that either translation or photography, or acting for that matter, are representational in any narrow sense of the term. Fidelity is our noble purpose, but it does not have much, if anything, to do with what is called literal meaning. A translation can be faithful to tone and intention, to meaning. It can rarely be faithful to words or syntax, for these are peculiar to specific languages and are not transferable. (Grossman, 2003)

A very blatant example of domestication at work is the pair of translators who translated Pushkin's work into English. They operate by doing both domestication and foreignization.

Profile 6. In an attempt to research the two translators separately, it was quite challenging to find any results that only include Larissa Volokhonsky or Richard Pevear. There is a sense that the prevalent dominance of the target language (in this case English) would not allow for a more well-constructed identity and presence of the translator who is associated to the source text.

"Leningrad-born Larissa Volokhonsky and the American Richard Pevear, who met in Manhattan in 1976, married, moved to France in the late '80s, and have since become the most prolific and prominent contemporary translators of Russian literature. The book they were autographing, Alexander Pushkin Novels, Tales, Journeys The Complete Prose (Knopf, Nov.), includes all the novels, tales, and journeys of the title, as well as several fragments, which were left unfinished in 1837 when Russia's greatest poet, not yet 40, died in a duel. (Alter, 2016, p.1-3).”

In a now-famous story, they were brought to the public consciousness when Oprah picked their Penguin Classics translation of Anna Karenina for her book club. As they've often explained in interviews since then, their work happens in separate offices. First, Volokhonsky, a native speaker of Russian, produces a complete first draft. Then Pevear, whose spoken Russian is not fluent, revises the draft, working to reproduce the writer's style coherently in English. (Alter, 2016, p.2).

It could be argued that (depending on how proficient Volokhnsky's English is of course) that Pevear mostly edits and renders the text into a more fluent and palatable text for the dominant Anglo-American readership expected, and yet since he belongs to the dominant target culture, he gets to provide all the paratextual material accompanying the translated text and ironically gets visibility through domesticating the text rather than foreignizing it. 


\section{Discussion}

Through viewing the six prefaces in the sample through different possible perspectives, such as the author of the preface (the translator) and the subject matter of the preface and comparing two different languages and ideologies that shared the same experience of translating from the same source text, this paper aimed to provide an adequately comprehensive context to achieve a clearer perspective of translators' prefaces and the implications of how they might provide several insights for further research. Through the comparison between the prefaces Arabic versus English, it would be very negligent to not see the larger context at hand. When the scope widens to include the profiles of the translators and the excerpts from their interviews, the concepts of power and ideology become evident. The domineering force by which a giant publishing company like Penguin Classics that have a rigidly consistent system that adopts (with all source texts regardless the language) what Venuti describes as a method of domestication that foregrounds the target culture and all its norms is one very obvious example of the power within language and ideology. In the two cases where the Arabic translators used a mediating text, it was English copies that were used, and the translator had access to the ST itself; this is an instance where looking at cases of indirect translation can be edifying in how it explains about the relationships between language, power, and ideology.

A clear disparity is evident in the relationships between the Arabic TTs and STs versus the English TTs and the STs. When the translators' profiles were revealed through their online visibility (or invisibility in the case of the Arabic translators) suddenly the missing preface for Love in the Time of Cholera does not cause much concern about the translator. The few glimpses of her interviews and speeches provide a very clear image of how accessible the author of the ST himself is to her; there is even a sense that her work is equivalent to that of the author, which is a good example of the concept of equivalence developed by Toury (1995). Another interesting finding is that one of the top results while searching entries for the translator Meredith McKinney is provided by a Japanese website. The sharp contrast between how two TTs of the same ST can display such strong difference in dominance and power over each other is an interesting reminder of how there is a lot to gain from this kind of analysis.

In the English TT of the Russian ST, although there were two translators involved (one of them a native speaker of the ST) only one translator was visible in the preface, the one who recontextualized the text appropriately in the TT. The process of translation and the shared roles were absent from the preface, except for the name mentioned on the cover and the pronoun "our", leaving the reader 
with the impression that only one translator was responsible for the whole process.

Another interesting finding is how Arabic translators (specifically the Russian ST) are prone to displaying several ideologically controlled texts. Some examples of these are the foregrounding of religious and conservative inclinations; in most cases even in positions that are irrelevant and do not serve any critical, artistic, or informative function.

One aspect to consider in this particular context is how Anthony Pym in his article Humanizing Translation History draws attention to how important it is to look for answers in viewing the "social role" that the translator plays to mediate between cultures. "Translators, the human producers of translations, might also be legitimate objects of knowledge. The background of the translators is at least as valid an organizing principle as having been the various focuses on sourcetext authors, source texts, or target-vs.-source languages, cultures or nations" (Pym, 2017, p.32). In light of all the constraints of living within this context, a lot of the translators' choices and decisions need to be reevaluated.

\section{Conclusion}

This paper attempted to explore the question of how the relationship between invisibility, social practice, and the translator's identity/role combined impact translators' choices in writing prefaces for translated literary works; the findings include a variety of evidence that confirms the intricacy of all these elements when analyzing paratextual material of translated works. Starting with the preface as part of the paratext as Batchelor (2018) mentioned that translation studies scholars focused on paratexts as "sites of translator intervention" or "adaptation of the text to its new environment" (p. 25) which summarizes some of the main features and functions required for this paper's discourse analysis and also the type of texts (discourse) being analyzed. Through researching the translators themselves in light of their profile and suggested or expected roles within this social practice, a clearer picture can be drawn.

The main findings of this paper indicated that the translator's situation in terms of visibility versus invisibility heavily affected their decisions in the process of production and the creation of discourse (prefaces). For instance, a powerful translator with enough power to obtain the original author's blessing such as Edith Grossman does not need all the features with functions as selfpromotion or assertion of visibility in her translation of Love in the Time of Cholera. On the other hand, a translator who lives in a target culture that idolizes domesticated versions of translated texts, with the disadvantage of using a mediating English text and with quite some distance (including a time gap) 
between the translator and author, the lack of power and visibility manifested in being part of a marginalized profession and a target language that in no way can match English as a target language, all this explains Tawfik Ali Mansour's nine pages long preface with all of its excessive features that in a lot of instances serve more as a reconstructed identity that ensures his role as an author, poet, and translator and his dominance throughout the text.

Another important finding to mention that pertains to the dimension of social practice is the difference in the order of discourse when it comes to the different socio-cultural settings. Ideas about how some themes in connection to the process of translation as making meaning are foregrounded while others are marginalized within different socio-cultural contexts. Through looking at some excerpts of the interviews with the translators, some of the salient observations would be the total agreement between all the translators using Arabic as TT on how marginalized and invalidated they are within their community. Furthermore, there is always a call for more attention to the importance and significance of translation and the effort and commitment it requires. Conversely, the excerpts from the interviews conducted with translators who translated in English show a very different setting. In two cases the translators very clearly stated that they just wanted to translate the texts with a very unconcerned attitude. The third translator was happy to describe how great the author of the text was through her meetings with him.

It is also important to mention that the comparison between Arabic translators and English translators when it comes to online visibility is somewhat discouraging; when any of the translators of the English TT was searched online, many results could be found, including Wikipedia entries, Social media, articles in magazines, personal websites, or even the organizations that they are affiliated with. On the other hand, when trying to collect information about the Arabic translators, it proved to be a challenging task because very few entries were found.

Some suggestions for future research would be addressing the question of indirect translation and mediating texts as options for translators in certain settings. Moreover, since this paper has a limitation in space for a larger and more comprehensive sample, it would be interesting to see the findings rendered with more data.

\section{References}

Alter, E. (2016, December 30). Lost in Translation: Richard Pevear and Larissa Volokhonsky. Retrieved from https:/www.publishersweekly.com/pw/by- 
topic/authors/profiles/article/72399-lost-in-translation-richard-pevear-andlarissa-volokhonsky.html

Bilodeau, I. (2012). Discursive Visibility: Quantifying the Practice of Translator Commentary in Contemporary Japanese Publishing. Center for Translation Studies CERTA, 31(1). doi: 10.1080/09555803.2018.1530280 Reteived from https://www.arts.kuleuven.be/cetra/papers/files/bilodeau

Devaney, T. (n.d.). Aiming the Lance of Language Translator of Contemporary Lit Takes on a Classic. Retrieved from https://www.sas.upenn.edu/sasalum/newsltr/spring04/grossman.html

Dimitriu, R. (2009). Translators' prefaces as documentary sources for translation studies. Perspectives, 17(3), 193-206. doi: 10.1080/09076760903255304 Retrieved from https://www.tandfonline.com/action/showCitFormats?doi=10.1080\%2F090 76760903255304

Fairclough, N. (1995). Critical discourse analysis: The critical study of language. London: Longman.

Fairclough, N. (2001). The dialectics of discourse. Textus, XIV(2), 231-242. Retrieved from: http://www.sfu.ca/cmns/courses/2012/801/1-Readings/ Fairclough\%20Dialectics\%20of\%20Discourse\%20Analysis.pdf

Gambier, Y., \& Doorslaer, L. van. (2013). Handbook of translation studies: volume 4. Amsterdam: John Benjamins Publishing Company.

Gambier, Y., \& Doorslaer, L. van. (2011). Handbook of translation studies. Amsterdam: John Benjamins Pub. Co.

Genette, G., \& Maclean, M. (1991). Introduction to the Paratext. New Literary History, 22(2), 261. doi: 10.2307/469037 Retrieved from https://internt.ht.lu.se/doc/1408547525.calendarEvents.6300.pdf.0.Introducti on_to_the_paratext.pdf/Introduction $\% 20$ to $\% 20$ the $\% 20$ paratext.pdf

Genette, G. (2001). Paratexts: Thresholds of interpretation. Cambridge: Cambridge University Press. Retrieved from: https://assets.cambridge.org/97805214/24066/frontmatter/9780521424066_f rontmatter.pdf

Grossman, E. (2014, December 21). Gabriel García Márquez remembered by Edith Grossman. Retrieved from https://www.theguardian.com/books/2014/dec/21/gabriel-garcia-marquezremembered-edith-grossman-translator

Kovala, U. (1996). Translations, Paratextual Mediation, and Ideological Closure. Target International Journal of Translation Studies Target, 8(1), 119-147. doi: 10.1075/target.8.1.07kov Retrieved from 
https://www.researchgate.net/publication/233645444_Translations_Paratext ual_Mediation_and_Ideological_Closure

Li, W. (2017). The Complexity of Indirect Translation. Orbis Litterarum, 72(3), 181-208. doi: 10.1111/oli.12148 Retrieved from https://www.researchgate.net/publication/317140860_The_Complexity_of_I ndirect_Translation_Reflections_on_the_Chinese_Translation_and_Recepti on_of_H_C_Andersen's_Tales

Marques, G. G., \& Grossman, E. (2016). Love in the Time of Cholera. New York: Penguin Publishing Group.

Marquez, G. G., \& Almani, S. (2013). الحب في زمن الكوليرا [Love in the Time of Cholera]. Beirut: Al-Mada.

Natsume, S., McKinney, M. and Natsume, S. (2010). Kokoro. New York: Penguin Publishing Group.

Natsume, S., \& Mohamed, A. (1988). كوروكو [Kokoro]. Baghdad: Dar AlMaamoun.

(n.d.). Meredith McKinney: Translators: Japanese Literature Publishing Project. Retrieved from https://www.jlpp.go.jp/en/translators/05_03_01.html

(n.d.). Edith Grossman. Retrieved from https://poets.org/poet/edith-grossman

(n.d.). فوز نهر النيل بجائزة الطوطاوي للترجمة [Nahr Al-Nil wins Al-Tahtawy award for translation].

Retrieved from http://almogaz.com/crime/news/2011/11/1/67979?amp

(n.d.). We are part of Penguin Random House, the world's leading trade publisher. Retrieved from https://www.penguin.co.uk/company/aboutus.html

(n.d.). Saleh Almani 2017 JUDGE. Retrieved from https://arabicfiction.org/en/Saleh-Almani

Pérez, M. C. (2001). A three-level methodology for descriptive-explanatory Translation Studies. Target. International Journal of Translation Studies Target, 13(2), 203-239. doi: 10.1075/target.13.2.02cal Retrieved from https://hathanhhai.files.wordpress.com/2012/11/a-three-level-methodologyfor-descriptive-explanatory-translation-theory.pdf

Picand, Y., \& Dutoit, D. (n.d.). Edith Grossman. Retrieved from http://dictionnaire.sensagent.leparisien.fr/Edith_Grossman/en-en/

Pushkin, A. S., \& Mansour, T. A. (2018). Hikāyāt Pushkin: majmū 'a qașașiya [Pushkin's tales a collection of stories].Cairo: Al-Makteb Al-Arabi LelMaaraf.

Pushkin, A. S., Pevear, R., \& Volokhonsky, L. (2016). Novels, tales, journeys: The complete prose of Alexander Pushkin. 
Pym, A. (2017). Humanizing Translation History. HERMES - Journal of Language and Communication in Business, 22(42), 23. doi: 10.7146/hjlcb.v22i42.96845 Retrieved from https://www.researchgate.net/publication/319381517_Humanizing_Translat ion_History

Toury, G. (2012). Descriptive translation studies and beyond. Amsterdam: John Benjamins. Retrieved from https://doi.org/10.1075/btl.100

Venuti, L. (2008). The Translator's Invisibility: A History of Translation (2nd ed.). New York: Routledge. Retrieved from http://citeseerx.ist.psu.edu/viewdoc/download?doi=10.1.1.475.4973\&rep=re $\mathrm{p} 1 \&$ type $=\mathrm{pdf}$

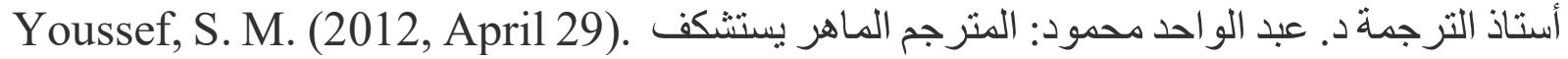
] A good translator is one who discovers the new and the exotic in others and never undermines his/her reader's intellect]. Retrieved from http://www.altaakhipress.com/printart.php?art=12284

صالح علماني: لهجة الأدب الأمريكي اللاتيني أرهقتني.س) Younis, A. (2018, December 4) [Saleh Almani: Latin American dialects wore me down]. Retrieved from https://www.albayan.ae/five-senses/dialogue/2017-07-10-1.2998844 